\title{
Entrevista
}

\section{Tereza Costa Rêgo: uma vida em busca da liberdade}

\author{
Adriano José de Carvalho
}

Há alguns anos atrás, tivemos o prazer de pesquisar com profundidade a vida da pintora pernambucana Tereza Costa Rêgo. Pelo fascínio que sempre alimentei por sua produção pictórica e por sua história de vida, tomei-a como objeto de estudo de minha dissertação no mestrado em Artes Visuais da Universidade Federal de Pernambuco e Universidade Federal da Paraíba. Nosso objetivo principal foi construir a trajetória biográfica desta artista, elucidando seu processo de criação e sua poética carregada de memórias pessoais; de imagens femininas e de uma reflexão sociopolítica da história nacional.

Na construção de nossa reflexão, além de documentos obtidos em fontes primárias, como livros, revistas e jornais, trabalhamos também com os discursos orais, obtidos nas cinco entrevistas que realizamos com Tereza durante o período de coleta de dados. Temos consciência da importância destas fontes orais para o conhecimento mais aprofundado da história de vida de nossa artista. No entanto, sabemos que tais relatos estão cheios de interferências pessoais, de ruídos emotivos e afetivos, incorrendo em trocas ou perdas ocasionadas pela relação do tempo com a memória humana, apresentando, por vezes, os fatos de maneira diferente. Como nos diz Henry Rousso, na história oral o indivíduo entrevistado sempre falará do fato passado estando inserido no seu presente, utilizando-se dos sentimentos, palavras e imagens do seu presente, mesmo que busque ser o mais verídico possível sobre o que aconteceu no passado (FERREIRA e AMADO, 2005, p 98).

Até mesmo os documentos históricos materiais (fotos, textos, vídeos) não estão isentos de mudanças ocasionadas pelas intenções, interpretações e possíveis manipulações dos agentes construtores dos mesmos, construindo daí uma imagem do sujeito ou do fato pesquisado. Comungamos com as ideias defendidas por France, ao afirmar a diferenciação entre a "coisa em si", no que tange a sua enticidade, e a "imagem da coisa", 
sendo esta um produto da experiência e interpretação humana. Como ela mesma nos diz: “Ora, aquilo que aparece na imagem não é exatamente igual àquilo que é apreendido pela observação direta.” Ou ainda: “(...) um objeto de duas faces: o homem e a imagem do homem” (FRANCE, 2000, p. 18). Consequentemente, há diferença também entre o modo com que nos relacionamos com as coisas no seu contexto real e as imagens dessas mesmas coisas, acarretando valorações, sentimentos, objetivos e respostas diferentes por parte dos indivíduos.

Apoiados em Pierre Bourdieu, fazemos uma distinção entre "vida", entendida como a vivência real do sujeito num determinado tempo e espaço, e "escrita da vida", como a ação estruturada num processo racional de registro dessa vivência. Como Bourdieu diz: “(...) o real é descontínuo, formado por elementos justapostos sem razão, todos eles únicos e tanto mais difíceis de serem apreendidos porque surgem de modo incessantemente imprevisto, fora de propósito, aleatório" (FERREIRA e AMADO, 2005, p.185). No entanto, ao tentarmos compreender a vida, ou dela nos apossar de modo racional, acabamos englobando-a em moldes lógicos que nos ajudam a entendê-la, a pensá-la, a organizá-la numa estrutura textual. A nossa razão impõe regras sistematizantes para os fatos vividos, por vezes desembocando numa estrutura de causa-efeito, seguindo uma linha cronológica, num processo de princípio-meio-fim. O próprio Bourdieu nos afirma: “(...) tratar a vida como história, isto é, como relato coerente de uma sequência de acontecimentos com significados e direção talvez seja conformar-se com uma ilusão retórica”; ou ainda, “(...) o relato autobiográfico se baseia sempre, ou pelo menos em parte, na preocupação de dar sentido, de tornar razoável, de extrair uma lógica” (FERREIRA e AMADO, 2005, p.184-185).

Endossados na palavra da própria artista, podemos dividir a sua trajetória de vida em três etapas, diferenciadas pelo nome que recebeu em cada uma delas: a primeira etapa refere-se a vida da "Terezinha", indicando a sua infância, adolescência e início de sua vida adulta. A segunda etapa é marcada pela "Camarada Joana", período da grande reviravolta de sua existência. E finalmente, a terceira etapa marca o apogeu de seu processo de legitimação profissional, quando assume definitivamente o nome artístico de Tereza Costa Rêgo, etapa iniciada após o seu retorno ao Brasil, em 1979. A partir deste momento, esta mulher se dedicou com afinco no processo de legitimação profissional de sua produção pictórica, vivenciando momentos significativos na história da arte de Pernambuco, como a Brigada Portinari; o atelier coletivo e a Oficina Guaianases de Gravura. Atualmente, em seus 87 anos de vida, e mais de 70 anos de produção artística, Tereza continua produzindo suas mulheres libertadas e libertadoras; seus bichos e plantas; sua análise crítica sobre a realidade sociopolítica do país.

Neste número da Cartema, abrimos o nosso material de pesquisa e compartilhamos diversas partes da entrevista com Tereza Costa Rêgo, realizada no dia 3 de junho de 2013, na residência da própria pintora. Interessante pontuar que, visando produzir um respeitado trabalho acadêmico, tentamos seguir todas as rígidas orientações para a elaboração da entrevista, preparando sequências lógicas de perguntas, pontuando objetivos específicos para cada uma delas e utilizando todos os recursos de registro que tínhamos 
à mão. Nosso intuito era tratar de assuntos específicos, como a história pessoal da pintora; a formação e influência artística; o seu processo de criação; a legitimação profissional; e a análise sobre sua produção pictórica.

No entanto, as coisas não aconteceram bem assim. Tereza é uma mulher livre de convenções e que não se sente muito bem com regras rígidas. $\mathrm{O}$ que nos impulsionou mudar drasticamente nossa ação. As entrevistas tornaram-se momentos de conversa; de partilha de vida; de confidências; de palavras ditas e registradas e muitas outras 'não-ditas'. Desde o primeiro encontro, os assuntos foram sendo misturados pela própria artista. Os botões dos gravadores eram ligados e desligados, tanto pelo entrevistador como também experiente entrevistada. Nós falamos, ouvimos, rimos, choramos, nos emocionamos, nos inquietamos e vivemos intensamente cada momento passado.

Adriano Carvalho (AC): Para iniciar esta entrevista, gostaria de saber como foi a sua participação nos salões artísticos de Pernambuco:

Tereza Costa Rêgo (TCR): Eu participei do Salão de Arte do Museu do Estado. Participei também do salão da Sociedade de Arte Moderna do Recife, que era uma coisa nova. Participei... nem me lembro mais.

Hoje em dia já não dou tanta importância como dava quando tinha quinze anos. Os Salões do Museu do Estado era sempre assim: Ganhava primeiro prêmio, Reinaldo Fonseca; Segundo, eu; Terceiro, Ricardo Brennand. Ou então, era primeiro, Brennand; segundo, Reinaldo; terceiro, eu.

AC: Como foi a sua experiência na Escola de Belas Artes?

TCR: A minha geração era eu, Maria Carmem, Ricardo Brennand, Reinaldo Fonseca, e Aluísio Magalhães. Era a época da Escola de Belas Artes.

Hoje, eu não colocaria minha filha pra fazer a Escola de Belas Artes.

Mas, não deixa de ser um exercício válido, durante alguns anos, de fazer desenho. Você ter uma noção de perspectiva, de composição.

Não quero dizer que hoje eu vou fazer aquela composição áurea. [...] Eu não faço mais isso que a gente aprendeu na Escola de Belas Artes.

Eu sou muito espontânea, mas, eu tenho um bom senso de espaço. Mas, isso é meu.

Então, para mim, às vezes, a Escola de Belas Artes me puxa pra baixo. Porque eu vou fazer uma mão; quero fazer um braço mais cumprido. Mas, não! O certo é aqui! A cabeça é sete vezes o tamanho da altura... essas coisas que a gente aprende e a gente começa a se autofiscalizar.

Mas, foi um período muito bom da minha vida.

Como eu era uma pessoa que não tinha liberdade nenhuma, eu fui muito reprimida por minha família.

A Escola de Belas Artes, para mim, era o céu. Porque eu vivia com essas pessoas, 
meu amigos e amigas.

Tinha um rio atrás da Escola. A gente gazeava as aulas, e ficávamos sentados na beira do rio.

Quer dizer, eu fui gente na Escola de Belas Artes.

Quando eu chegava em casa, eu era trancada em casa e tirava a chave.

Então, a Escola de Belas Artes foi uma janela aberta para mim. A primeira janela para o mundo.

E eu tive a sorte já de pegar aqueles artistas do Rio de Janeiro, que vieram para cá, com o senso da arte moderna: Vicente do Rego Monteiro e Lula Cardoso Aires. Que foram muito importantes para a minha formação artística.

Principalmente o Lula.

Nas suas aulas, invés de eu fazer a cabeça sete vezes o tamanho do corpo, ele deixava a gente fazer o que quiséssemos. E eu me soltei.

A minha mão... quem desamarrou a minha mão, na Escola de Belas Artes, foi Lula.

Tenho um carinho muito grande por ele.

AC: E o Vicente do Rego Monteiro?

TCR: Vicente era mais longe. Foi muito importante para mim. Mas, eu me identifiquei mais com o Lula.

AC: É verdade que sua família não permitia que você participasse das aulas de modelo vivo na Escola de Belas Artes?

TCR: Sim! Mas eu fugia!

E o professor Murilo La Greca gostava muito de mim. Deixava eu entrar.

Agora, você veja que não adianta você reprimir as coisas. Porque, hoje, eu só pinto mulher nua.

Eu fugia mesmo das outras aulas pra assistir modelo vivo mesmo, porque era o que eu queria aprender.

E não era por causa de peito, bunda, etc, não.

Era porque era mão. Era movimento. Era o rosto que eu tinha vontade de pintar.

Nessa época, Reinaldo (Fonseca) é um pouco mais velho do que eu, e ele desenhava muito bem. E eu ficava com inveja de ver ele fazer aquilo com uma rapidez incrível. E eu queria aprender modelo vivo.

E era pecado... e ia pro inferno.

Então... fui pro inferno e ainda estou.

E estou achando ótimo. (risos)

(A artista começou a falar sobre o seu processo de criação artística)

TCR: Eu sou meio transgressora! 
Invés de pintar sobre o branco, eu pinto a tela toda de preto primeiro.

E eu não desenho.

Por exemplo, todos esses quadros que você está vendo aí, eu vou pintando já com a tinta.

É uma doidice!

Quando eu pinto sobre o branco a tinta fica ruim. Eu acho que a tinta passada sobre o preto, ela ganha uma transparência.

Às vezes, alguns quadros, você tem que fazer pesquisa.

Por exemplo, Tejucupapo ${ }^{1}$, eu tenho que fazer pesquisa. Guararapes ${ }^{2}$ eu também fiz.

Mas, Guararapes eu tive influência muito grande daqueles ex-votos de igreja, que tem sobre a batalha dos Guararapes ${ }^{3}$.

Zé Claudio que diz que minha pintura tem influência... ele não utilizou a palavra 'ex-voto'. Ele diz que tem alguma coisa de pintura de teto de igreja.

É a pátina do tempo que eu faço manualmente.

Ele diz que eu faço um trabalho parecido com predela. Não tem um altar mor de madeira no meio da igreja? E aqui, na frente dessa peça tem sempre uma pintura. São José e nossa senhora fugindo do Egito, uma coisa assim, sabe?

E isso quando vai envelhecendo, vai tomando uma pátina, que eu aprendi a fazer essa pátina daqui.

Mas, é uma coisa minha.

Reinaldo (Fonseca) faz de um jeito, eu faço de outro. Reinaldo faz com o pincel, eu faço com o dedo. Por isto que eu tive uma intoxicação danada.

Eu tenho que alisar.

Maria Tereza diz que eu não pinto. Eu não olho. Eu aliso!

Eu aliso as paredes de Olinda. Eu aliso...

Eu tenho que ser tátil. Tudo tem que ser tátil.

Eu pinto desde criança!

A Escola de Belas Artes foi muito boa para mim porque eu não saia de casa.

Eu ia pro colégio de freira e voltava com chofer.

Uma de nossas vizinhas não sabia que tinha uma menina ali. Acreditava que só haviam os meninos.

Então, a Escola de Belas Artes, para mim, era a hora que eu saia; que eu conversa-

$\infty<\infty<\infty<\infty<\infty<\infty \times \infty \times<\times<\infty<\infty<\infty$

1 A artista se referiu à obra que estava trabalhando neste momento, intitulada 'Mulheres de Tejucupapo'. Até hoje, este grande painel ainda não foi apresentado oficialmente ao público.

2 Referência à pintura 'Batalha dos Guararapes ou Árvore da Liberdade’. Acrílico sobre madeira. 160 X 220 cms. 2009. Da série 'Sete Luas Sangue. Ver fig. 001.

3 Referências aos ex-votos cênicos da Batalha dos Guararapes expostos no Museu do Estado de Pernambuco. 
va com Reinaldo (Fonseca); que eu conversava com Aluísio Magalhães, entendeu?

Que eu era livre.

Eu comecei a pintar assim... toda criança tem seus lápis de cera, não é?

Depois, eu fui aluna de uma freira francesa, chamada madame leucadier, do Colégio Damas.

Então, eu aprendi a pintar flores. Aquela coisa de freira. Umas florzinhas.

As primeiras coisas que eu pintei foi com aquarela.

Um raminho; um passarinho; assim.

Depois, meu irmão mais velho convenceu a mim, à minha mãe e ao meu pai, que eu deveria ir para Escola de Belas Artes.

Eu devia ter uns quatorze, quinze anos.

AC: Mas, você não fez o curso de artes plásticas completo?

TCR: Não! Eu não podia!

Eu não podia assistir nú (disciplina de modelo vivo), pois diziam que ia pro inferno.

Eu fiz o curso livre, convivendo com Mario Nunes, Murilo La Greca, Reinaldo Fonseca, Lula Cardoso Aires"

AC: Tereza, em outros momentos, você me falou que cursou História, na Sorbonne, na França:

TCR: Sim. Cursei história. Meu orientador chamava-se professor Pierre Vilar. Ele morreu. Ele era uma grande figura da Sorbonne. Ele gostava muito de mim.

O título da tese na Sorbonne foi: "A formação do proletariado no Brasil: uma classe em si e uma classe para si.

Ah, eu estudei muito pra fazer isso. [...] Às vezes, essas coisas da minha vida passam assim, e eu digo: "não fui eu, não! Não fui eu que tava lá, não!”

Aí eu vejo uma foto e penso: eu estava. Aí eu digo: "olha eu aqui!"

AC: Como você conceitua a sua própria arte? Moderna? Contemporânea?

TCR: Eu gostaria muito de assistir uma pessoa importante falar o que é contemporâneo. [...]

A minha pintura...

Não sei o que é contemporâneo!

Não sei se sou uma pintora contemporânea! [...]

Para mim existem somente duas coisas: É bom ou é ruim. É abstrato bom, é abstrato ruim. É figurativo bom, é figurativo ruim. 
AC: Existe uma predominância de figuras femininas em suas pinturas. Como você entende o gênero feminino?

TCR: Olhe, eu vou citar (Oscar) Niemeyer. Ele tem na sala dele um desenho de uma mulher. E ele diz que a curva... da mulher... a curva da mulher é a mais bonita que existe.

Eu acho o corpo da mulher muito bonito.

E eu fui muito reprimida também.

AC: Tereza, eu concebo que nas suas obras existe muito de uma alto-biografia. Você concorda comigo?

TCR: Eu acho que tem alguma coisa haver.

(João) Câmara diz que a minha pintura é na primeira pessoa do singular.

Eu não acho, não. Porque eu contextualizo tudo o que eu gosto de ser.

Como é que eu posso dizer? Não sei!

Se eu pudesse definir a minha pintura, eu acho que plasticamente a minha pintura sempre tem dois planos: dentro e fora. [...]

E é o muito grande e o muito pequeno.

E tenho uma obsessão por algumas coisas: Pelos bichos! Sempre tem bichos no meu trabalho. É raro não ter. Porque eu me sinto mais um bicho do que uma pessoa.

Antes de qualquer coisa eu sou um animal.

Eu acho que meu nu é muito delicado.

Eu não acho que minha pintura... eu não acho que seja erótica. [...]

Eu acho que o corpo nu é muito verdadeiro.

Veja, aqui, esse quadro de cima ${ }^{4}$. Foi quando eu... foi quando eu descobri que Diógenes ${ }^{5}$ tinha morrido. Que eu me deitei sobre ele e fazia assim (movimento com as mãos como que balançando o corpo de Diógenes), e ele não acordava.

Eu quis dar um beijo, mas a sua boca não respondia.

Foi quando eu percebi que ele tinha morrido.

Eu percebi que ele tinha morrido em cima dele. [...]

Aquilo ali (a artista apontou para o plano de fundo do quadro), são colagens dos bilhetes que ele escrevia quando estava na prisão.

$\infty<\infty<\infty<\infty<\infty<\infty<\infty<\infty<\infty<\infty<\infty<\infty$

4 Neste momento, a artista apontou para a obra intitulada 'A partida'. Acrílico e colagem sobre madeira. 220 x 80 cms. 1981. Ver fig. 002.

5 Referência ao seu segundo marido e grande companheiro de vida, Diógenes Arruda Câmara. Líder comunista que foi preso, torturado e exilado pelo regime militar, na década de 1960. Diógenes faleceu subitamente pouco tempo depois do retorno de seu exílio. 
E eu desenhei essas figuras assim ${ }^{6}$, são pessoas que eu não lembrava da cara delas, mas que estavam lá quando eu cheguei no hospital.

O pior é que eu sou forte. Eu dizia assim: "Diógenes tem honras parlamentares".

Aí, Aldarante dizia: "Você tá doida, Joana? A anistia foi ontem!".

Aí, eu disse: "Mas, Diógenes foi o deputado mais votado em São Paulo em 1950. Ele tem honras parlamentares. Ele deve ficar num lugar público.".

Aí, eu disse: "Vocês não querem ir, não? Eu vou! Eu vou na assembleia.”.

Eu não chorava. Só pensava no que Diógenes gostaria que fosse feito.

Aí, Genuíno foi com esse menino que eu não estou lembrando o nome. Era o marido de Marta Suplici. Aí, ele disse: "De jeito nenhum! Vamos parar toda a sessão, preparar para esperar o corpo de Diógenes..

Aí, eu disse: "Eu queria uma bandeira do partido comunista!".

E me diziam: "Joana, você parece que não chegou no Brasil. Não tem nenhuma condição.".

Eu respondia: "Você não quer me ajudar, não? Eu vou comprar fazenda e vou fazer a bandeira do partido!".

Aí, um homem, amigo meu, disse: "Eu faço, Tereza... Joana, pra você"

Aí, eu puxei a bandeira brasileira para baixo e botei a do partido comunista.

Eu tenho essas coisas de fidelidade ao partido. Eu achava que ele (Diógenes) gostaria que acontecesse aquilo. Acho que ele gostaria de ficar na assembleia onde ele foi deputado, não é?! Eu gostaria que tivesse a bandeira do partido.

Eu não chorava, não. Chorava pra dentro. As lágrimas caiam todas pra dentro.

Quando eu vi que Diógenes estava morto, dentro de mim eu pensei: "Meu deus! Agora eu não tenho mais nada!" Mas, logo em seguida pensei: "Não! Agora eu vou ser eu! E agora eu vou ser uma pintora profissional! A única coisa que eu quero agora é pintar!"

\section{Referências bibliográficas}

FERREIRA, Marieta de Moraes, AMADO, Janaína (org.). Usos e abusos da história oral. Rio de Janeiro: Fundação Getúlio Vargas, 2005.

FRANCE, Claudine de. Do filme etnográfico à antropologia fílmica. Campinas: Editora da Unicamp, 2000.

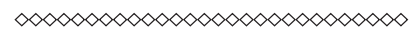

6 A artista apontou para as diversas faces que foram pintadas no plano de fundo da obra 'A Partida'. Ver fig. 002 . 


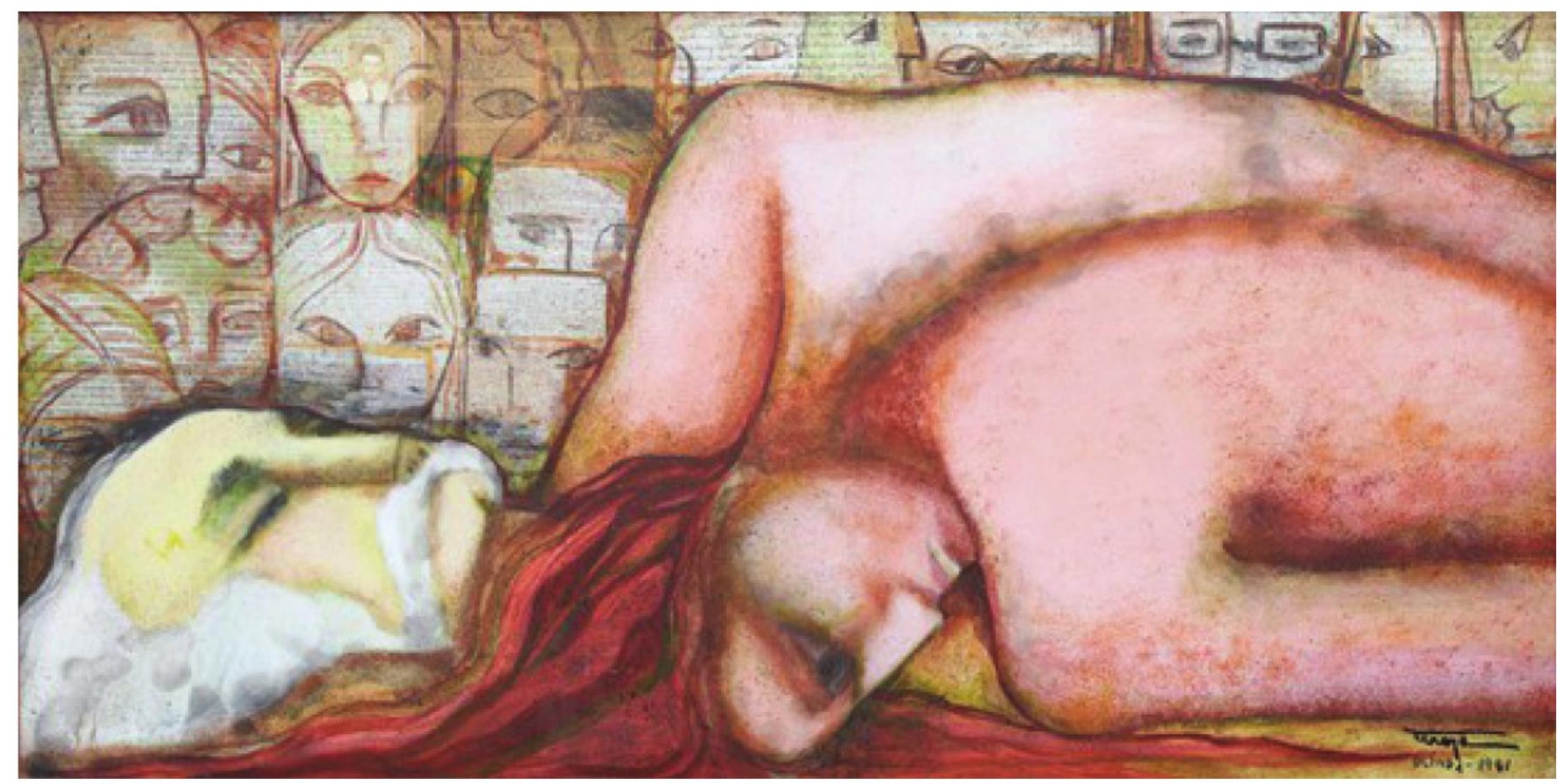

Fig. 2 -Tereza Costa Rêgo. “A partida”. Acrílico e colagem sobre madeira. 220 X 080. 1981. Fonte: RÊGO, 2009, p. 101. 